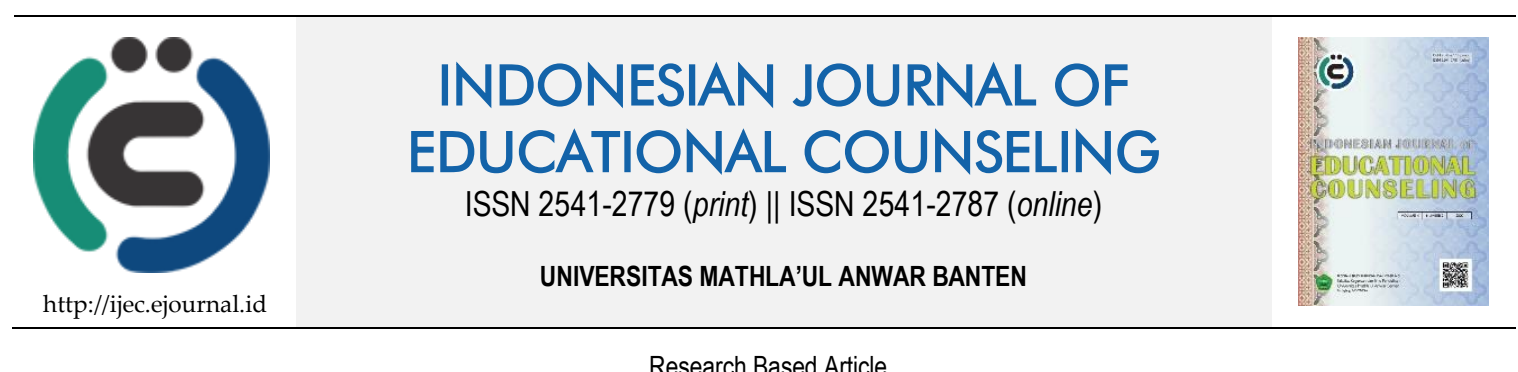

Research Based Article

\title{
Perilaku Sosial Anak 5-6 Tahun dalam Kegiatan Sentra Bermain Peran di TK Labschool Jakarta
}

\author{
Yuliani Eka Putri ${ }^{1}$, Nurbiana Dhieni², Hapidin ${ }^{2}$ \\ 1, 2 Universitas Negeri Jakarta, Indonesia
}

\begin{tabular}{ll}
\hline Article History & ABSTRACT \\
\hline Received: 05.03.2020 & SOCIAL BEHAVIOR OF CHILDREN AGED 5-6 YEARS IN ROLE PLAYING \\
Received in revised form: & CENTER ACTIVITIES AT TK LABSCHOOL JAKARTA. This study aims to find \\
Accepted: 25.06.2020 & and build theories of the forms of social behavior of children 5-6 years in the \\
Available online: 20.07.2020 & role playing center activities, the process of the formation of social behavior of \\
& children 5-6 years in the role playing center activities, the role of the teacher in \\
& the formation of social behavior of children 5-6 years in the role playing center \\
& activities, as well as the role of parents in shaping the social behavior of children \\
& 5-6 years in the role playing center activities. This research uses a qualitative \\
& approach with a case study method. The results of the study found that the \\
& social behavior of children 5-6 years old in Labschool Kindergarten Jakarta \\
& showed social behavior related to human relations, namely good human \\
& relations (social humanity), namely empathy, tolerance, cooperation, \\
& responsibility, fair, close behavior, share and wait their turn.
\end{tabular}

KEYWORDS: Early Childhood, Role Playing Centers, Social Behavior.

DOI: $10.30653 / 001.202042 .139$

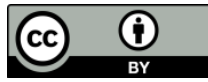

This is an open access article distributed under the terms of the Creative Commons Attribution 4.0 International License, which permits unrestricted use, distribution, and reproduction in any medium, provided the original work is properly cited. ๑ 2020 Yuliani Eka Putri, Nurbiana Dhieni, Hapidin.

\section{PENDAHULUAN}

Sejak dini penting bagi anak diajarkan perilaku sosial untuk membangun kepribadian yang positif. Mahardika (2014) mengemukakan bahwa perilaku sosial merupakan suatu hubungan timbal balik antar individu dan lingkungan, dimana lingkungan berpengaruh terhadap tingkah laku seseorang yang melibatkan kognitif untuk menentukan individu menerima ataupun menolak pengaruh dari lingkungan. Hal ini berarti bahwa manusia sebagai makhluk sosial memerlukan orang lain untuk bersosialisasi dan lingkungan memiliki pengaruh terhadap pembentukan perilaku seseorang.

Mengoptimalkan dan mengembangkan perilaku sosial anak dapat dilakukan dengan berbagai cara salah satunya melalui pendidikan. Pendidikan anak usia dini merupakan sarana untuk meningkatkan tumbuh kembang anak dimana pendidikan menjadi fondasi awal untuk mengembangkan dan mengoptimalkan aspek perkembangan

${ }^{1}$ Corresponding author's address: Universitas Negeri Jakarta. Jl. Rawamangun Muka, RT.11/RW.14, Rawamangun, Kec. Pulo Gadung, Kota Jakarta Timur, Daerah Khusus Ibukota Jakarta 13220, Indonesia. Email: yulianiekaputri_paud17s2@ mahasiswa.unj.ac.id 
pada anak. Nanik Iis (2012) menyebut bahwa pendidikan merupakan salah satu cara dalam mengembangkan perilaku sosial anak dimana terdapat pembelajaran pembentukan perilaku yang mengandung nilai-nilai positif sesuai dengan anak TK. Penyediaan lingkungan yang baik untuk anak dapat mengembangkan kemampuan sosialisasi anak dalam bertingkah laku agar dapat diterima dalam masyarakat.

Sekolah menjadi lingkungan kedua yang ditemui oleh anak setelah keluarga. Sekolah menjadi sarana pendidikan untuk anak belajar bersosialisasi. Burroughs (2018) dalam penelitiannya mengemukakan bahwa sekolah memiliki fungsi untuk menyediakan lingkungan agar anak dapat bersosialisasi dengan lingkungannya. Lingkungan yang baik akan menanamkan nilai etika yang sesuai dengan norma dan kaidah yang berlaku di masyarakat. Selain itu, di lingkungan juga dapat membangun hubungan yang positif baik hubungan anak dengan guru, hubungan anak dengan anak lainnya maupun hubungan anak dengan masyarakat luar. Oleh karena itu, sekolah memiliki peranan terpenting dalam membentuk perilaku pada anak dan menjadi wadah bagi anak untuk belajar bersosialisasi.

Melalui bermain anak dapat memupuk dan mengoptimalkan aspek perkembangannya. Menurut studi yang dilakukan oleh Farida \& Friani (2018) menunjukkan bahwa manfaat interaksi teman sebaya terhadap perilaku sosial anak usia dini di RA Muslimat NU 007 Gandu 1 Mlarak Ponorogo antara lain memberikan dukungan sosial, moral, dan emosional, anak dapat belajar untuk saling menghargai orang lain. Melalui bermain memiliki sikap tanggung jawab, belajar bekerja sama, saling berbagi dan peduli terhadap kondisi teman yang lain. Bermain bukan hanya sekedar untuk bersenang-senang bagi anak, tetapi dalam bermain anak-anak memperoleh keterampilan baru, menyiapkan diri untuk hidupnya kelak jika telah dewasa dan dengan bermain membantu anak mencapai perkembangan yang utuh baik fisik, intelektual, sosial, moral dan emosional.

Selanjutnya hasil penelitian Andriati (2016) menunjukkan bahwa model bimbingan kelompok dengan teknik bermain peran efektif meningkatkan interaksi sosial siswa. Jadi pendapat ini menegaskan bahwa bermain peran merupakan kegiatan yang dapat membangun perilaku sosial anak. Perilaku sosial ini dibangun karena dalam permainan anak berupaya mengekspresikan watak dan karakter peran yang dimainkannya. Dengan mengekspresikan watak tersebut, anak mampu menilai tentang perilaku yang benar dan salah. Selain itu, melalui bermain peran anak juga belajar membangun interaksi dengan pasangan teman bermainnya. Oleh karena itu, bermain peran dapat membangun perilaku sosial anak.

Berdasarkan hasil wawancara dengan kepala sekolah, bahwa Taman Kanak-kanak Labschool Jakarta ini memang benar mengutamakan bagaimana penanaman nilai-nilai perilaku sosial pada anak. Perilaku sosial ini sudah menjadi hidden kurikulum di sekolah ini, maksudnya dari pembiasaan perilaku di sekolah sudah mengutamakan pembentukan perilaku sosial bukan dari program unggulan tetapi dari tujuan sekolah hal ini terlihat dari salah satu misi Taman Kanak-kanak Labschool Jakarta yaitu bagaimana menciptakan pembelajaran diferensial yang humanis, kreatif dan holistik. Kurikulum pada Taman Kanak-kanak Labschool Jakarta dinamakan dengan kurikulum integratif dengan mengintegrasikan nilai-nilai sosial dalam pembelajaran. Kurikulum ini secara isi dipadukan dengan metode Beyond Centre $\mathcal{E}$ Circle Time salah satunya konsep dalam kegiatan sentra bermain peran. Konsep sentra yang dipergunakan disesuaikan dengan 
nilai-nilai budaya sekolah Labschool serta visi dan misi Labschool. Kegiatan sentra bermain peran merupakan suatu upaya pada lembaga ini dalam mengintegrasikan pembelajaran untuk menanamkan perilaku sosial pada anak.

Pada kegiatan sentra bermain peran ini, guru memberikan trik dalam bermain, kemudian anak bermain sendiri, jadi anak mempraktekan langsung bagaimana anak dapat bekerjasama dalam suatu tim/kelompok. Jadi dalam setiap cerita yang anak perankan ada perilaku yang guru tanamkan dalam diri anak, anak akan cepat berkomunikasi dengan orang lain dan memiliki rasa kepedulian yang kuat di antara sesama kelompok bermainnya. Adapun penataan ruang kelas dalam sentra bermain peran yaitu guru mensetting keadaan kelas sesuai dengan tema/subtema dengan menggunakan properti-properti yang menggambarkan sesuai dengan cerita atau peran yang anak mainkan jadi dengan hal itu seolah-olah anak benar berada dalam lingkungan cerita yang dimainkan.

Pada kegiatan bermain peran ini, tampak bagaimana antusiasnya perilaku yang ditunjukkan anak dalam bermain, anak saling berkomunikasi dan berinteraksi. Perilaku menghargai ditunjukkan melalui anak mengalah ketika temannya telah memilih peran yang akan dimainkan, anak mengingatkan temannya yang tidak bermain dengan benar. Perilaku tanggung jawab ditunjukkan melalui anak menyelesaikan perannya masingmasing, tetap berada di posisi peran yang dia mainkan, mengembalikan kostum yang dipakai kepada guru. Perilaku kerjasama ditunjukkan melalui anak bersama-sama menyelesaikan peran yang dimainkan, membantu teman yang lain dalam bekerja. Perilaku toleransi ditunjukkan melalui anak dapat menghargai kemampuan temannya dalam bermain, anak dapat beradaptasi dengan lingkungan yang berbeda, tidak memilihmilih teman dalam bermain. Perilaku berbagi ditunjukkan melalui anak dapat membagi makanan dan minumannya. Perilaku empati ditunjukkan melalui anak secara responsif membujuk temannya yang lagi sedih untuk ikut bergabung dan bermain dengan teman lainnya.

Sejak kecil anak telah belajar cara berperilaku sosial sesuai dengan harapan orangorang yang ada di sekitarnya. Menurut Hapidin (2015) menyatakan bahwa perilaku sosial merupakan dimensi perkembangan sosial yang paling tampak, nyata dan dapat diamati secara langsung. Kutipan ini mempertegas bahwa perilaku sosial merupakan dimensi utama yang menentukan perilaku seseorang dalam kehidupan sehari-hari. Baik atau tidaknya perilaku seseorang terlihat dari sikap anak dalam bersosialisasi. Bersosialisasi yang dimaksud mulai dari bersosialisasi dengan teman sebaya dan orang dewasa.

Pendapat lain juga mengatakan tentang perilaku sosial Wiyani (2014) mengungkapkan bahwa perilaku sosial merupakan kegiatan yang berhubungan dengan orang lain, kegiatan yang berkaitan dengan pihak lain yang memerlukan sosialisasi dalam hal berperilaku yang dapat diterima oleh orang lain, belajar memainkan peran yang dapat diterima oleh orang lain, serta upaya mengembangkan sikap sosial yang layak diterima oleh orang lain. Perilaku sosial berhubungan dengan semua orang dalam berbagai kegiatan maupun aktivitas sehari-hari. Jadi perilaku sosial ini akan menentukan bagaimana anak berinteraksi dengan orang lain.

Perilaku terbentuk dari apa yang anak lihat pada orang lain. Bandura dalam teori pembelajaran sosial menyatakan bahwa seorang individu belajar perilaku sosial dengan mengamati dan meniru orang lain. Proses ini dikenal dengan istilah modeling atau 
pembelajaran observasional. Meniru atau menjadi orang lain yang dilakukan anak adalah salah satu cara bagaimana anak dapat diterima baik oleh kelompoknya. Pembelajaran yang dilakukan melalui peniruan dengan meniru orang-orang yang ada di lingkungannya merupakan salah satu cara dalam membentuk perilaku anak. Anak belajar membentuk perilaku dari pengamatan terhadap perilaku orang lain (Papalia 2010).

Lingkungan memiliki peran yang sangat penting dalam pembentukan perilaku. Masnipal (2013) menyatakan bahwa lingkungan yang positif membentuk perilaku yang positif pula sedangkan lingkungan yang negatif juga membentuk perilaku anak yang negatif. Lingkungan tersebut antara lain keluarga, lingkungan sekolah, guru, sumber belajar, dan lingkungan teman sebaya anak. Hal ini merupakan suatu tanda bahwa faktor lingkungan sangat erat hubungannya dengan perilaku sosial anak. Lingkungan tersebut adalah lingkungan yang sehari-hari ditemui oleh anak, bahkan semua kegiatan yang dilakukan anak berkaitan dengan lingkungan tersebut. Maka dari itu sangat diwajibkan untuk seorang pendidik dan keluarga agar selalu bekerja sama memberi hal-hal yang positif terhadap lingkungan anak, agar perilaku sosial yang positif dapat tercipta.

Vygotsky menyatakan bahwa interaksi sosial yang dibangun dengan orang dewasa dan teman sebaya dapat membantu perkembangan kognitif anak. Pengalaman dan kegiatan sehari-hari yang dilakukan anak akan membawa pengaruh pada anak khususnya pada perilaku sosial anak. Melalui interaksi anak belajar tentang bagaimana beradaptasi dengan lingkungannya dan menjadikan anak sebagai orang yang sukses untuk ke depannya. Interaksi merupakan suatu kegiatan komunikasi yang dilakukan anak dengan orang lain, maka dapat dipahami bahwa komunikasi memberi pengaruh pada anak. Dengan kutipan ini diperjelas bahwa perkembangan yang terjadi pada anak yaitu melalui interaksi (Santrock, 2015).

Perilaku yang ditunjukkan anak merupakan cerminan dari perlakuan lingkungan sekitar anak. MacDonald et al (2016) mengungkapkan bahwa interaksi anggota keluarga dan guru di sekolah dapat mengembangkan perilaku sosial anak. Interaksi anak dengan gurunya di sekolah merupakan bagian dari hubungan sosial anak di sekolah. Disini, guru bertanggung jawab dalam menciptakan suatu hubungan sosial yang baik dengan anak untuk mengarahkan perilaku anak. Guru merupakan contoh bagi anak dalam berperilaku selama anak di sekolah.

Pembentukan perilaku tidak terlepas dari peran orang dewasa. Kostelnik et al., (2012) mengungkapkan bahwa orang dewasa membantu anak-anak untuk mempertahankan perilaku yang diinginkan dengan strategi pengajaran dan pembinaan yang dilakukan oleh guru seperti membuat model pengajaran, berdiskusi, mengajarkan, mengarahkan, mengingatkan serta menindaklanjuti membantu anak. Pendapat ini menegaskan bahwa guru dapat membantu anak-anak untuk merubah perilaku yang tidak sesuai menjadi perilaku yang sesuai dengan aturan lingkungan. Tugas guru adalah bagaimana perilaku anak terbentuk dengan baik. Guru bukan hanya membentuk tetapi juga contoh bagi anak yang akan ditiru anak dalam berperilaku.

Pembentukan perilaku anak mulai di bangun dari keluarga. Moswela (2017) menyatakan bahwa perilaku anak dipengaruhi terutama oleh latar belakang keluarganya dan oleh karena itu orang tua bertanggung jawab atas perilaku anak di sekolah. Pendapat ini menegaskan bahwa sebelum lingkungan sekolah orangtua lah yang bertanggung jawab penuh atas perilaku anak. Latar belakang orangtua mempengaruhi dalam 
pembentukan perilaku anak kedepannya. Oleh karena itu orangtua harus memberikan didikan yang tepat dalam pembentukan perilaku anak. Perilaku yang ditunjukkan anak dalam lingkungan sekolah dan masyarakat merupakan gambaran dari pola asuh orangtuanya.

Kasmadi (2013) mengungkapkan bahwa perilaku anak adalah cerminan gaya hidup dari kedua orangtuanya, atau bisa juga dari pembiasaan atau budaya lingkungan yang mendidiknya. Pendapat ini menjelaskan bahwa perilaku yang ditampilkan anak merupakan gambaran dari stimulasi yang diberikan oleh orangtuanya. Peran keluarga merupakan dasar pertama dan utama sebagai fondasi yang sangat berpengaruh dalam pembentukan perilaku anak sampai usia selanjutnya. Jika orangtua mampu memberikan pembinaan perilaku yang baik kepada anak maka perilaku anak kedepannya akan baik. Jadi pembinaan yang diberikan oleh orangtua harus sejalan dengan pembinaan yang diberikan di sekolah oleh karena itu dibutuhkan kolaborasi orangtua dan guru dalam pembentukan perilaku anak yang sesuai.

Melalui bermain peran dapat mengarahkan perilaku seseorang. Myers (2010) menyatakan bahwa dalam bermain peran bagaimana suatu tindakan buatan dapat secara signifikan mempengaruhi keadaan yang nyata. Pendapat ini menegaskan bahwa dalam permainan pura-pura dapat memberikan pengaruh yang nyata kepada perilaku seseorang. Melalui permainan ini dimana guru mengenalkan langsung informasi yang ingin dikenalkan pada anak salah satunya yaitu perilaku sosial. Dengan anak berperan sebagai orang lain anak merasakan bagaimana menjadi orang tersebut dengan itu mereka akan belajar dari pengalaman yang mereka alami langsung.

Bermain peran dapat membangun hubungan sosial anak dengan orang lain. Uno (2016) menyatakan bahwa bermain peran suatu model pembelajaran bertujuan untuk membantu siswa menemukan makna dirinya di dunia sosial dan memecahkan masalah dengan bantuan kelompok. Hal ini memberikan kesempatan kepada anak untuk bekerja sama dengan lingkungan sosial. Jadi salah satu cara untuk membentuk perilaku sosial yang positif anak dengan kegiatan bermain peran.

\section{METODE}

Metode penelitian yang digunakan dalam penelitian ini adalah studi kasus. Studi kasus merupakan suatu tipe kajian penelitian kualitatif yang memfokuskan pada suatu objek tunggal, individu, suatu kelompok, suatu institusi atau lembaga, dan suatu organisasi. Tujuan dari studi kasus adalah untuk mendapatkan gambaran atau mendeskripsikan dan pemahaman secara mendalam tentang keseluruhan kasus. Pada penelitian ini, peneliti ingin mendeskripsikan atau memotret suatu gejala nyata atau situasi sosial yaitu perialku sosial anak 5-6 tahun dalam kegiatan sentra bermain peran di Taman Kanak-kanak Labschool Jakarta, secara luas dan mendalam tanpa melakukan intervensi.

Teknik pengumpulan data menggunakan observasi, wawancara dan dokumentasi. Dalam penelitian ini yang digunakan sebagai analisis data yaitu dengan mencocokkan pola atau pattern matching Yin (2013). Dalam penelitian ini menggunakan menggunakan teknik penjodohan Campbell. Analisis ini menurut Yin adalah dengan membandingkan pola yang didasarkan pada pola empirik dengan pola yang telah diprediksi di awal 
sebelum mengumpulkan data. Jika kedua pola ini ada persamaan, hasilnya dapat menguatkan validitas internal studi kasus yang bersangkutan.

\section{HASIL DAN PEMBAHASAN}

Hasil penelitian didapatkan bahwa perilaku sosial anak 5-6 tahun di Taman Kanakkanak Labschool Jakarta menujukkan perilaku sosial yang berkaitan dengan hubungan kemanusiaan yaitu hubungan baik sesama manusia (social humanity) yaitu empati, toleransi, kerja sama, tanggung jawab, adil, perilaku akrab, berbagi dan menunggu giliran.

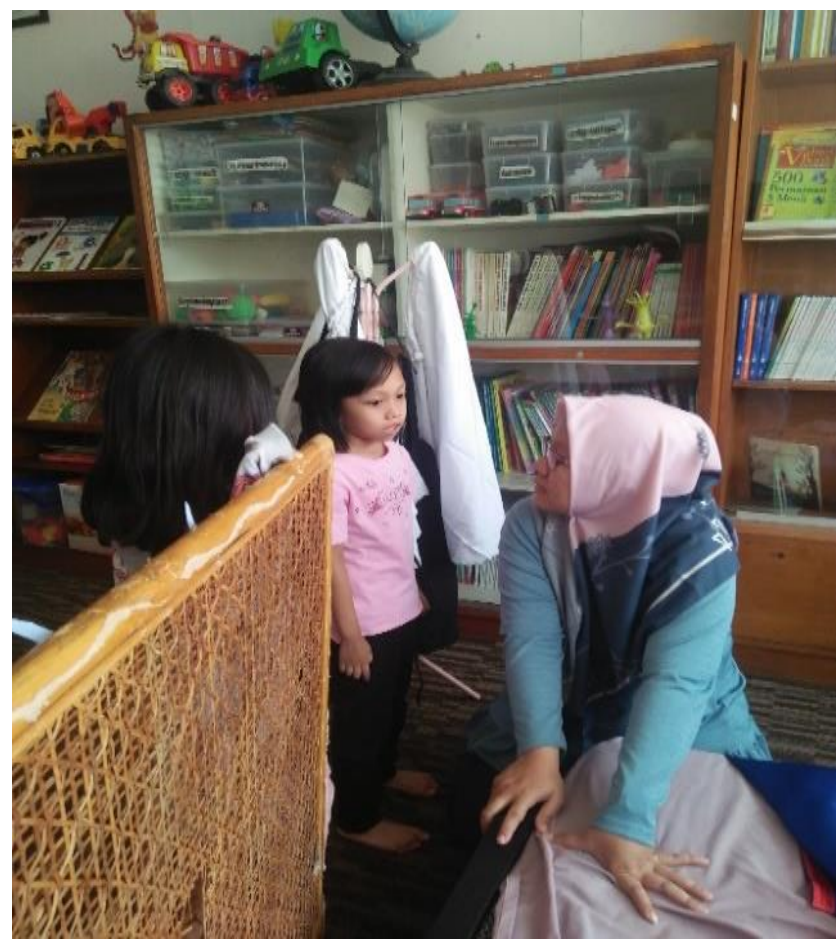

Gambar 1. Anak menyemangati teman yang sulit dalam memilih peran

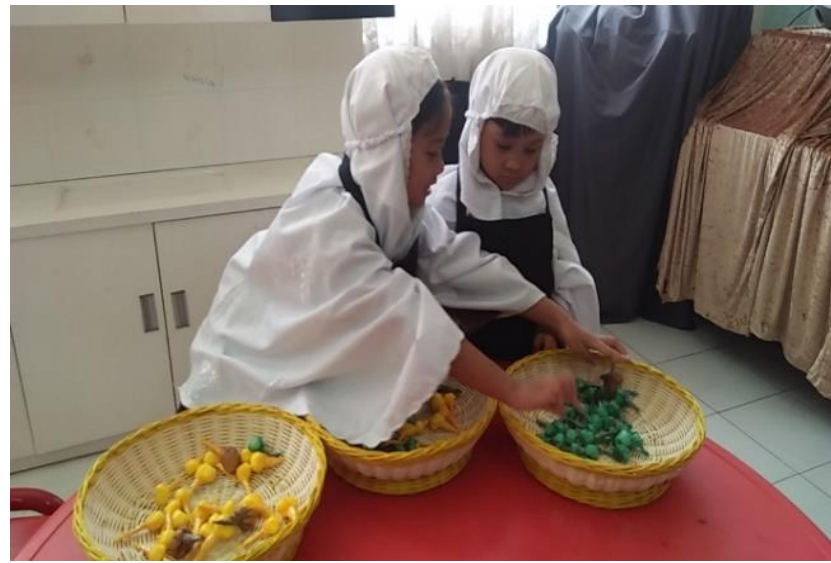

Gambar 2. Anak saling tolong menolong dalam memisahkan kurma 


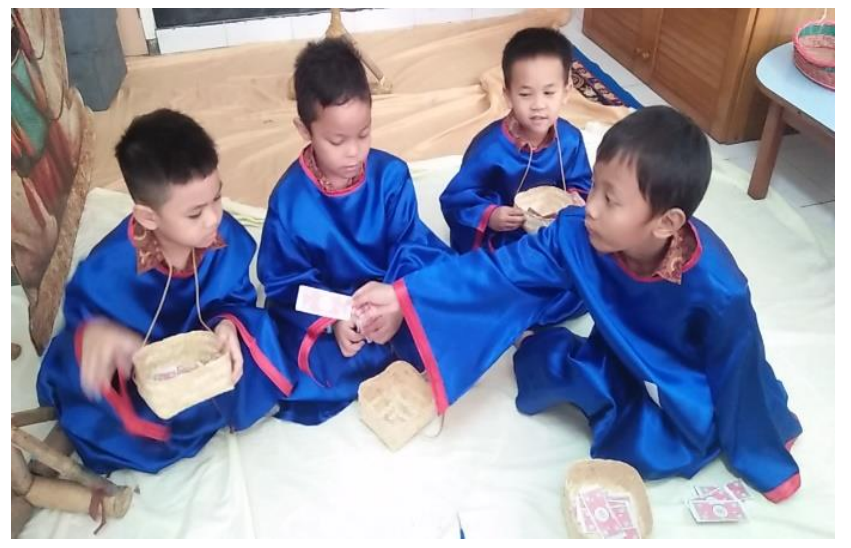

Gambar 3. Anak membagi upah sama banyak kepada karyawan

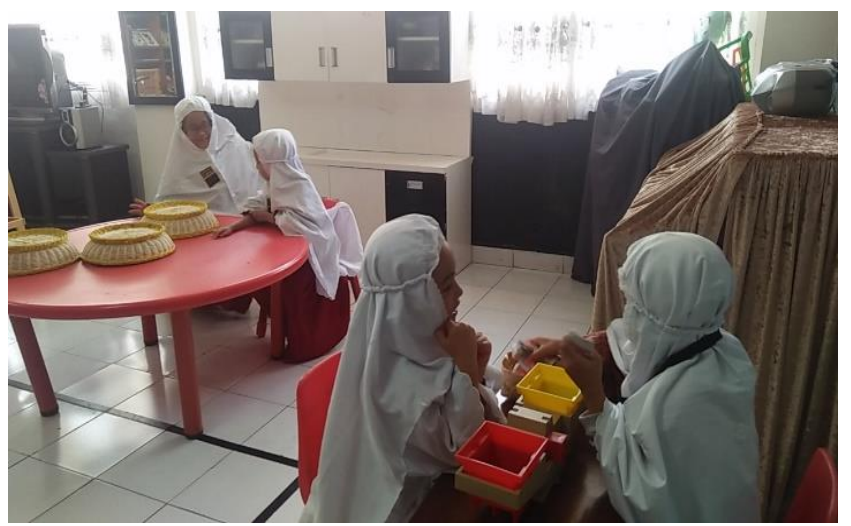

Gambar 4. Anak dapat menyesuaikan diri dan berinteraksi dengan anak lain

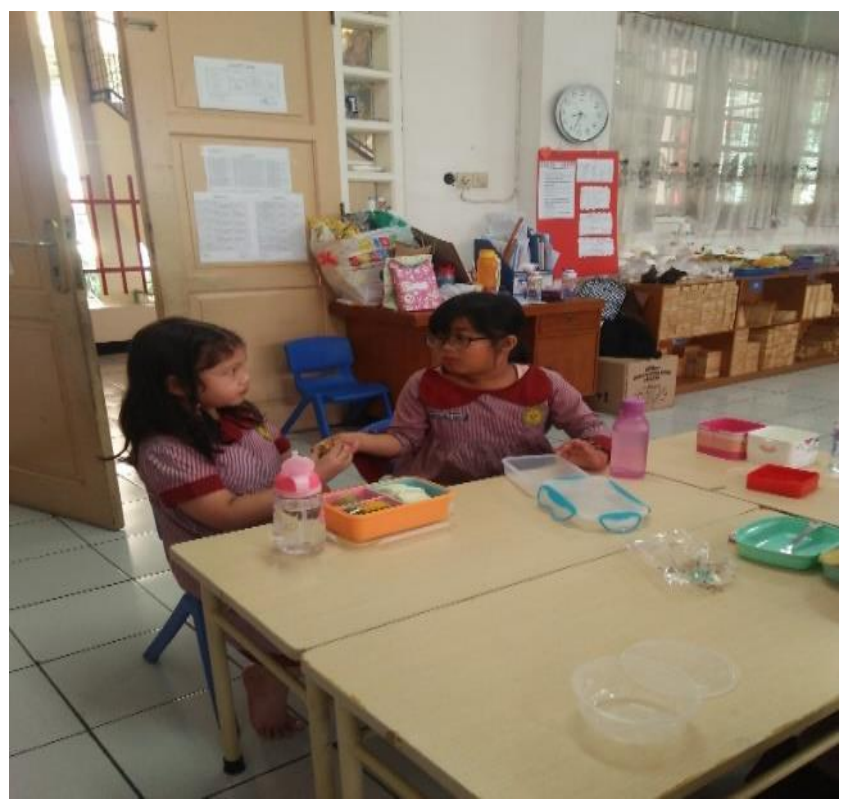

Gambar 5. Anak berbagi makanan dengan temannya 


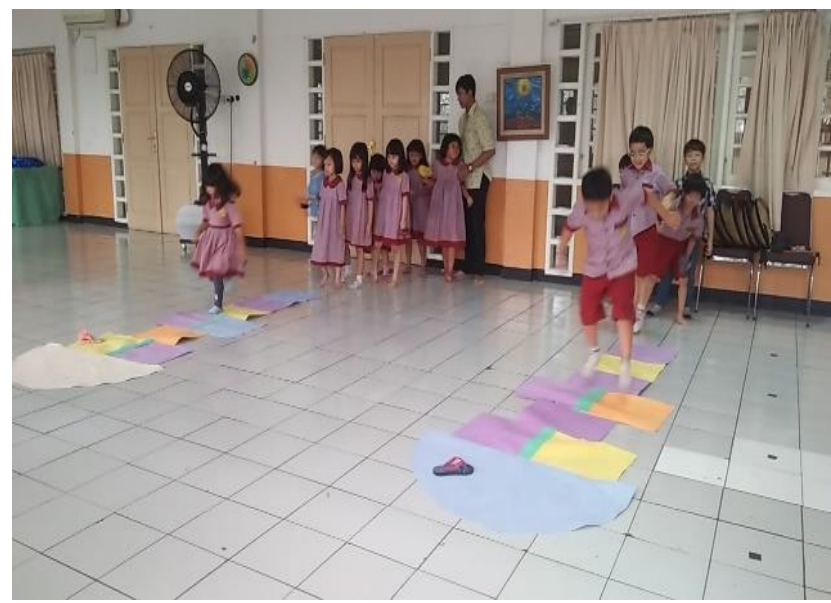

Gambar 6. Anak menunggu gilirannya dalam bermain

Minartin (2013) mengemukakan bahwa perilaku sosial anak merupakan kemampuan anak dalam menjalin hubungan yang baik dengan sesama teman, guru, maupun orangtua. Jadi dapat dikatakan perilaku sosial baik dalam aktivitas sehari-hari maupun dalam berbagai kegiatan berhubungan dengan semua orang. Perilaku sosial menjadi salah satu aspek yang penting untuk dikembangkan sebagai bekal kehidupan anak untuk masa yang akan datang. Didalam menjalin hubungan dengan orang lain anak mengalami peristiwa yang bermakna dalam kehidupannya dan membantu anak membentuk kepribadian.

Bentuk-bentuk perilaku sosial yang ditemukan di Taman Kanak-kanak Labschool Jakarta sejalan dengan penelitian yang di lakukan oleh Tunçgenç \& Cohen (2016), perilaku anak-anak yang terlibat dalam bermain sinkron menujukkan secara signifikan lebih saling bekerjasama, ramah, saling berbagi dan empati.

Numan (2015) menyatakan bahwa perilaku sosial terdiri dari perilaku-perilaku yang diperlihatkan oleh seseorang individu ketika mereka berinteraksi dimana perilaku tersebut dapat berbentuk prososial ataupun anti sosial. Perilaku prososial memberikan manfaat terhadap lingkungannya seperti kerja sama, perilaku kelekatan dan sikap menghargai (altruisme). Sedangkan perilaku anti sosial perilaku yang tidak memberikan manfaat baik bagi diri sendiri maupun oranglain berbentuk agresi dan perilaku seksual.

Rachmana \& Budiani (2013), bentuk perilaku sosial anak usia dini yang mendapatkan pembelajaran bilingual, hasil penelitian ini menunjukkan bahwa perilaku sosial yang terbentuk adalah mengalah, tidak mengejek dan menggertak, tidak pernah bertengkar, mau berbagi makanan dan minuman, bisa mematuhi aturan, bisa membaur dengan yang lain, memberi dukungan, ramah, mandiri, mau bekerjasama, mau membantu, mudah beradaptasi, berperilaku atas inisiatif sendiri dan berperilaku baik yang menjadi ciri khas dari masing-masing subjek.

\section{SIMPULAN}

Taman Kanak-kanak Labschool Jakarta merupakan salah satu lembaga pendidikan anak usia dini yang mengintegrasikan nilai-nilai sosial dalam pembelajaran salah satunya melalui kegiatan sentra bermain peran. Oleh karena itu, hasil temuan penelitian perilaku sosial anak 5-6 tahun dalam kegiatan sentra bermain peran yaitu menujukkan perilaku 
sosial yang berkaitan dengan hubungan kemanusiaan yaitu hubungan baik sesama manusia (social humanity) yaitu empati, toleransi, kerja sama, tanggung jawab, adil, perilaku akrab, berbagi dan menunggu giliran.

\section{REFERENSI}

Andriati, N. (2016). Model bimbingan kelompok dengan teknik bermain peran untuk meningkatkan interaksi sosial siswa. Jurnal Konseling GUSJIGANG, 2(2), 125-132.

Burroughs, M. D. (2018). Ethics Across Early Childhood Education. In E. Englehardt (Ed.), Ethics Across the Curriculum-Pedagogical Perspectives (pp. 245-260). Cham: Springer.

Farida, N., \& Friani, D. A. (2018). Manfaat interaksi teman sebaya terhadap perilaku sosial anak usia dini di RA Muslimat NU 007 Gandu 1 Mlarak Kabupaten Ponorogo Provinsi Jawa Timur. JURNAL SOSIAL: Jurnal Penelitian Ilmu-Ilmu Sosial, 19(2), 169175.

Hapidin. (2015). Asesmen dan evaluasi pendidikan anak usia dini. Jakarta: LPP Press UNJ.

Iis, N. (2012). Pengembangan Empati Anak Usia Dini Melalui Mendongeng di Taman Kanak-Kanak Asyiyah Pariaman. Jurnal Ilmiah Pesona PAUD, 1(4), 1-11.

Kasmadi. (2013). Membangun soft skills anak-anak hebat. Bandung: Alfabeta.

Kostelnik, M. J., Gregory, K. M., Soderman, A. K., \& Whiren, A. P. (2012). Guiding children's social development and learning (Seventh Ed). USA: Wadsworth.

MacDonald, M., Lipscomb, S., McClelland, M. M., Duncan, R., Becker, D., Anderson, K., \& Kile, M. (2016). Relations of preschoolers' visual-motor and object manipulation skills with executive function and social behavior. Research Quarterly for Exercise and Sport, 87(4), 396-407. doi: 10.1080/02701367.2016.1229862

Mahardika, E. K. (2014). Peningkatan perilaku sosial anak melalui permainan tardisional jawa. Pendidikan Usia Dini, 8(2). doi: 10.21009/JPUD.082.06

Masnipal. (2013). Siap Menjadi guru dan pengelola PAUD profesional. Jakarta: Kompas Gramedia.

Minartin. (2013). Meningkatkan perilaku sosial anak melalui metode kerja kelompok pada kelompok A di TK Aisyiyah Bustanul Athfal Toboli. Jurnal Kreatif Tadulako Online, 1(3), 157-171.

Moswela, B. (2007). Students' Behaviour Problems are Rooted in the Family-Parents to be Held Liable. Journal of Social Sciences, 15(2), 111-116.

Myers, D. G. (2010). Social psychology (ten edition). New York: McGraw-Hill. 
Numan, M. (2015). Neurobiology of social behavior: toward an understanding of the prosocial and antisocial brain. USA: Elsevier.

Papalia, D. E., Old, S. W., \& Feldman, R. D. (2010). Human development (Kesembilan). Jakarta: Kencana.

Rachmana, Y. S., \& Budiani, M. S. (2013). Perilaku sosial pada anak usia dini yang mendapat pembelajaran bilingual. Character: Jurnal Penelitian Psikologi, 2(1), 1-13.

Santrock, J. W. (2015). Life Span development (Fifteenth). New York: McGraw-Hill Education.

Tunçgenç, B., \& Cohen, E. (2016). Interpersonal movement synchrony facilitates pro-social behavior in children's peer-play. Developmental Science, 21(1), 1-23.

Uno, H. B. (2016). Model pembeajaran: Menciptakan Proses belajar mengajar yang kreatif dan efektif. Jakarta: Bumi Aksara.

Wiyani, N. A. (2014). Psikologi perkembangan anak usia dini. Yogyakarta: Gava Media.

Yin, R. K. (2014). Case study research: Design and methods (5th Ed). USA: Sage. 